\title{
Age, growth and mortality of southern rays bream Brama australis (Bramidae) off the southeastern Pacific coast
}

\author{
Edad, crecimiento y mortalidad natural de la reineta Brama australis (Bramidae) \\ en la costa este del Pacífico sur
}

\section{Ciro Oyarzún ${ }^{1}$, Nelson Cortés ${ }^{2}$ and Elson Leal ${ }^{3}$}

\author{
${ }^{1}$ Departamento de Oceanografía, Sección Pesquerías, Universidad de Concepción, Concepción, P.O. Box 160-C, Chile \\ ${ }^{2}$ Unidad de Recursos Hídricos, Servicio de Evaluación ambiental, Ministerio de Medio Ambiente, Lincoyan N²145, \\ Concepción, Chile \\ ${ }^{3}$ División de Investigación Pesquera, Instituto de Fomento Pesquero, Blanco 839, Valparaíso, Chile. elson.leal@ifop.cl
}

\begin{abstract}
Resumen.- Se determinó la edad, función de crecimiento y mortalidad natural de la reineta Brama australis provenientes de capturas comerciales realizadas en la zona central de la costa de Chile. Los resultados indican que la especie crece rápidamente durante el primer año y alcanza la máxima longitud asintótica $(59 \mathrm{~cm})$ aproximadamente al octavo o noveno año de edad. La función de crecimiento de von Bertalanffy describió satisfactoriamente el crecimiento en longitud a través de la edad de $B$. australis, determinada mediante el análisis de los otolitos. Los parámetros estimados para ambos sexos combinados fueron: en longitud, $L_{\infty}=58,95 \mathrm{~cm}, \mathrm{~K}=0,277$ año-1 $\mathrm{t}_{0}=-0,371$ años; $y$ en peso, $\mathrm{W}_{\infty}=2508,8 \mathrm{~g}, \mathrm{~K}=0,257$ año-1, $t_{0}=-0,712$ años. No se encontraron diferencias en la longitud a la edad entre sexos. La tasa de mortalidad total ( $\mathrm{Z}$ ) desde el análisis de la edad máxima y curva de captura fue relativamente alta $\left(0,9\right.$ año $\left.{ }^{-1}\right)$. La tasa de mortalidad natural $\left(0,45\right.$ año $\left.^{-1}\right)$ es consistente con los parámetros de vida de un pez pelágico de tamaño medio, de explotación relativamente baja en el periodo en que fueron colectadas las muestras.
\end{abstract}

Palabras clave: Bramidae, edad y crecimiento, mortalidad, Pacifico sureste, reineta

\begin{abstract}
The age and growth function and mortality were determined for southern rays bream Brama australis caught in commercial trawls off the coast of central Chile. The results show that this species grows quickly in the first year and reaches the maximum asymptotic length $(59 \mathrm{~cm})$ at approximately 8 or 9 years old. The von Bertalanffy growth function described $B$. australis growth satisfactorily with length-at-age determined using otolith analysis. Parameters for the entire population (males and females) were: for length, $\mathrm{L}_{\infty}=58.95 \mathrm{~cm}, \mathrm{~K}=0.277 \mathrm{yr}^{-1}, \mathrm{t}_{\mathrm{o}}=-0.371 \mathrm{yr}$; and for weight, $\mathrm{W}_{\infty}=2508.8 \mathrm{~g}, \mathrm{~K}$ $=0.257 \mathrm{yr}^{-1}, \mathrm{t}_{\mathrm{o}}=-0.712 \mathrm{yr}$. No differences were found in length-at-age between sexes. Estimates of total mortality rates $(\mathrm{Z})$ from maximum age and catch-curve analyses were relatively high $\left(0.9\right.$ year $\left.^{-1}\right)$. The natural mortality rate $\left(\mathrm{M}=0.45 \mathrm{yr}^{-1}\right)$ is consistent with the life parameters of middle-sized pelagic fish with relatively low exploitation at the time of sampling.
\end{abstract}

Key words: Bramidae, age and growth, mortality, eastern South Pacific, southern rays bream

\section{INTRODUCTION}

The Southern rays bream, Brama australis Valenciennes, 1838 , is a member of the family Bramidae that is exploited by the artisanal fleet along the Chilean coastline. According to Mead (1972) and Last \& Baron (1994), this family inhabits epipelagic ecosystems at depths over 200 $\mathrm{m}$, although it has been reported at depths exceeding 400 to $500 \mathrm{~m}$. B. australis is widely distributed in the South Pacific Ocean; it has an apparent circumpolar distribution in the hemisphere and is restricted to the circulation boundaries of the subtropical water masses $\left(35^{\circ}-48^{\circ} \mathrm{S}\right)$ (Pavlov 1991a).
Until a few years ago, B. australis was not considered to be a commercially important species. Rather, it was caught as bycatch during trawling for Patagonian grenadier (Macruronus magellanicus Lönnberg, 1907) and Chilean jack mackerel (Trachurus murphyi Nichols, 1920) (Muñoz et al. 1995). However, B. australis is currently highly valued for human consumption in central Chile. Official records were begun for B. australis catches off the Chilean coast in 1994 (SERNAPESCA 2011). The mean landings have increased from 5000 tons $(\mathrm{t})$ between 1994 and 2000 to over $15000 \mathrm{t}$ since 2010 (Fig. 1). The 


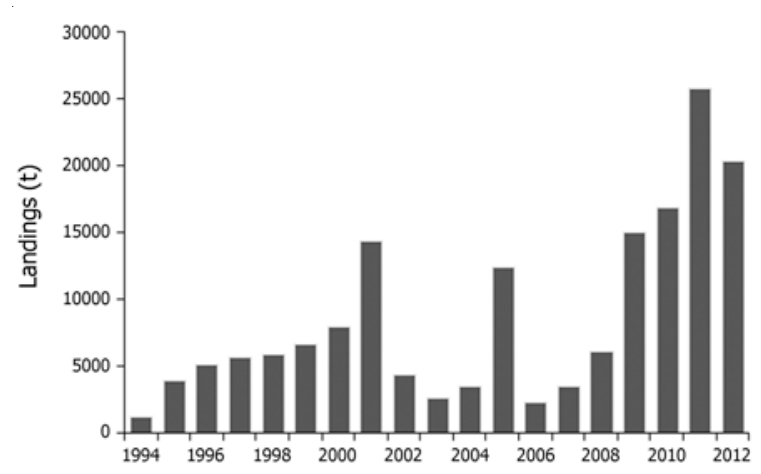

Figure 1. Total landings of southern rays breams registered in Chile from 1994 / Desembarques totales de reineta registrados en Chile desde 1994

fishery shows seasonality with higher catches during spring-summer from October to April.

Information on the biology and ecology of B. australis is limited despite its newfound ecological and commercial importance for the artisanal fleet. Pavlov (1991a, b, 1994) performed morphometric, taxonomic, ecological and reproductive studies on members of the Brama genus from southeastern Pacific Ocean. Muñoz et al. (1995) and Garcia \& Chong (2002) studied the feeding habits of $B$. australis off the coast of central Chile, characterizing this species as a secondary consumer that preys mostly on crabs, squids, and small fishes, as it has been reported in other species of Brama (Seki \& Mundi 1991, Pearcy et al. 1993). Leal \& Oyarzún (2003) described B. australis reproduction along the Chilean coast, reporting higher reproductive activity in winter and an active female maturation process over $35 \mathrm{~cm}$ fork length.

Given the lack of reliable information on biological parameters for this species, the objetive of this work was to study growth and mortality in the eastern South Pacific population of $B$. australis based on otolith age analysis of annual increments in their otoliths.

\section{Materials And Methods}

Sampling took place between $35^{\circ} 20^{\prime} \mathrm{S}$ and $38^{\circ} 50^{\prime} \mathrm{S}$ off the eastern South Pacific coast (Fig. 2). Specimens were collected monthly from November 1994 to December 1996 from pelagic commercial fisheries. Fishes were sexed macroscopically, and measured for total length $\left(L_{T}, \mathrm{~cm}\right)$ and total weight $\left(W_{\mathrm{T}}, \mathrm{g}\right)$. Sagittal otoliths were taken from each specimen and stored in dry bags. Prior to analysis, each left otolith was hydrated in distilled water from 24 to $48 \mathrm{~h}$. The external surface of each otolith was examined microscopically under reflected light.
Organisms were aged by counting the number of growth marks found in the otoliths. Prior to aging the individuals, a periodicity analysis was done to evaluate the formation of annual growth bands. The number of translucent zones on each otolith and the nature of the border were recorded.

To assess the precision of aging, all otoliths were read twice by 2 different readers and the agreement between and within readers was evaluated by percent agreement methods (Beamish \& Fournier 1981). Lack of consensus resulted in the otolith being rejected as «noninterpretable» and excluded from analysis.

After age determination, parameters of the von Bertalanffy growth function (BGF, Ricker 1975) in length, $L_{\mathrm{t}}=\mathrm{L}_{\infty}\left(1-\exp \left(-\mathrm{k}\left(\mathrm{t}-\mathrm{t}_{\mathrm{o}}\right)\right)\right.$ and weight, $W_{\mathrm{t}}=\mathrm{W}_{\infty}(1-\exp (-\mathrm{k}$ $\left.\left(t-t_{0}\right)\right)^{b}$ were obtained. Where $L_{t}$ and $W_{t}$ are the length $(\mathrm{cm})$ and weight $(\mathrm{g})$ of fish aged $\mathrm{t}$ (years) respectively, $\mathrm{L}_{\infty}$ and $\mathrm{W}_{\infty}$ are the theoretically maximum length $(\mathrm{cm})$ and weight (g) respectively, $K$ is coefficient of growth, $t_{0}$ is theoretical age at which the length of fish is 0 and $b$ is slope parameter in the length-weight relationship.

The parameters of BFG were fitted using non-linear regression (the NONLIN module of SYSTAT v.7, Wilkinson 1988) with a Gauss-Newton algorithm, where growth parameters and the residual sum of squares (RSS) were obtained from each iteration (1000) through quadratic minimization. Growth curve parameters were compared between sexes with RSS analysis modified for non-linear minimum squares (Chen et al. 1992).

A length-weight relationships $\left(\mathrm{W}=a^{*} T_{\mathrm{L}}^{b}\right)$ was fitted to the data and utilized to calculate the parameters used in BGF for weight. $T_{\mathrm{L}}$ is a total length, $a$ and $b$ are regression coefficients. The estimated value $a$ that came from the logarithmic scale (Smith 1990) was transformed to an arithmetic function. The growth performance index $\mathrm{f}=$ $\log _{10}(\mathrm{~K})+2 / 3 \log _{10}\left(\mathrm{~W}_{\infty}\right)$ was computed from the growth parameters for comparing with another species (Sparre \& Venema 1997).

A catch curve-at-age was constructed by expanding the length-frequency distribution at abundance caught at age. The total mortality rate $(\mathrm{Z})$ for both sexes was determined from the descending limb of the curve according to Sparre \& Venema (1997).

The lack of data concerning fishing effort and the unavailability of data on unfished areas made it not possible to make a direct estimation of natural mortality rate $(\mathrm{M})$. Instead, empirical models based on the 


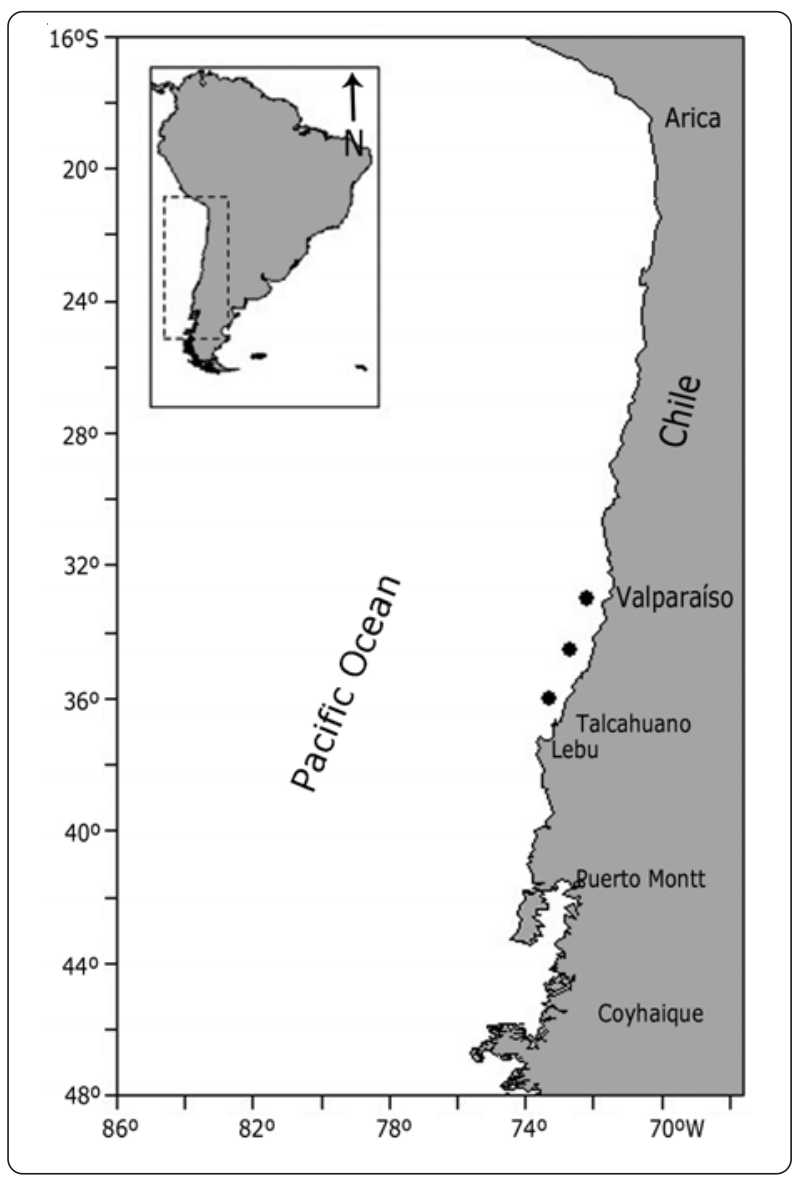

Figure 2. Geographic location of the study on the central coast of Chile. The black points indicate the approximate sampling sites / Localización geográfica del estudio en la costa central de Chile. Los puntos negros indican los sitios aproximados de muestreo

relationships between $\mathrm{M}$, growth parameters and mean habitat temperature $\left(\mathrm{T}^{\circ} \mathrm{C}\right)$ were used to obtain approximate estimates (Pauly 1980). Additionally, Alagaraja (1984), proposed an alternative method of estimating $\mathrm{M}$ by relating to the natural life span of fish which was defined as an age at which $1 \%$ of a cohort is still alive ( $\mathrm{T}_{1}$, years). This approach was also used in order to provide an estimate of the natural mortality rate in B. australis.

\section{Results}

A total of 534 adult breams were analyzed. Individuals ranged from 21 to $58 \mathrm{~cm} T_{\mathrm{L}}$. Of the total specimens measured, 109 were discarded due to otolith breakage or loss or because they were classified as non-interpretable, as defined in the methods section.

The edge analysis showed that the percentage of translucent (hyaline) edges increased markedly in those periods in which opaque edges decreased, showing one peak per 12-month period and thereby demonstrating that the translucent zones (hialine bands) are formed annually.

Individuals of both sexes showed age range between 2 to 8 years i.e., from 2 to 8 marks (hialine bands). In terms of numbers, most males were younger (2-4 years) and most females older (5-7 years). For both sexes, 4 yearsold specimens showed the highest frequency. The VBFG equations for male, female and for pooled are showed in the Fig. 3.

Observed lengths did not vary greatly with age. Growth was fast in the first years of life and slow from year 7 onward. Southern rays bream achieve $50 \%$ of their $\mathrm{L}_{\infty}$ at age 2, apparently one year before the recruitment to the fishery.

No differences were found in growth curve parameters for length between the sexes $(P>0.05)$. We did not observe large numbers of either the youngest or oldest fish.

The weight of the southern rays bream varied greatly with age. As it was found for age-length data, growth was rapid in the first 4 years. Although it slowed thereafter, the fish still grew appreciably in weight until 10-11 years, at which point growth substantially slowed. Hence, the fish grew apparently more slowly in weight than in length. The BGF equation for pooled data was: $W_{\mathrm{t}}$ $=2508.8\left(1-\exp (-0.257(t+0.712))^{2.84}\right.$. Table 1 shows the estimated parameters, asymptotic standard errors (ASE), and $95 \%$ confidence intervals. The growth performance of $B$. australis was $\phi=1.67$. A pooled length-weight regression (Fig. 4) with a fitted value for $a$ was developed $\left(\mathrm{R}^{2}=0.97 ; \mathrm{n}=425 ; P<0.01\right)$. The slope of the regression line $(b=2.84 ; \mathrm{SE}=0.067)$ was significantly different from $3.0(P<0.05)$, indicating allometric growth.

Table 1. Summary of estimated parameters for the von Bertalanffy growth equation of total length $(\mathrm{cm})$ and total weight $(\mathrm{g})$ of Brama australis for the pooled data / Resumen de los parámetros estimados por la ecuación de crecimiento de von Bertalanffy para la longitud total $(\mathrm{cm})$ y peso total (g) de Brama australis para el total de los datos

\begin{tabular}{cccccc}
\hline Measurement & Parameter & Estimate & ASE & $\begin{array}{c}\text { Lower lim. } \\
(95 \%)\end{array}$ & $\begin{array}{c}\text { Upper lim. } \\
(95 \%)\end{array}$ \\
\hline Length $(\mathrm{cm})$ & $L_{4}$ & 58.952 & 2.176 & 54.675 & 63.23 \\
& $K$ & 0.277 & 0.034 & 0.21 & 0.345 \\
& $t_{o}$ & -0.371 & 0.217 & -0.799 & 0.056 \\
\multirow{4}{*}{ Weight $(\mathrm{g})$} & $W_{1}$ & 2508.8 & 65.073 & 2367 & 2650.6 \\
& $K$ & 0.257 & 0.005 & 0.215 & 0.299 \\
& $t_{o}$ & -0.712 & 0.05 & -0.821 & -0.604 \\
\hline
\end{tabular}




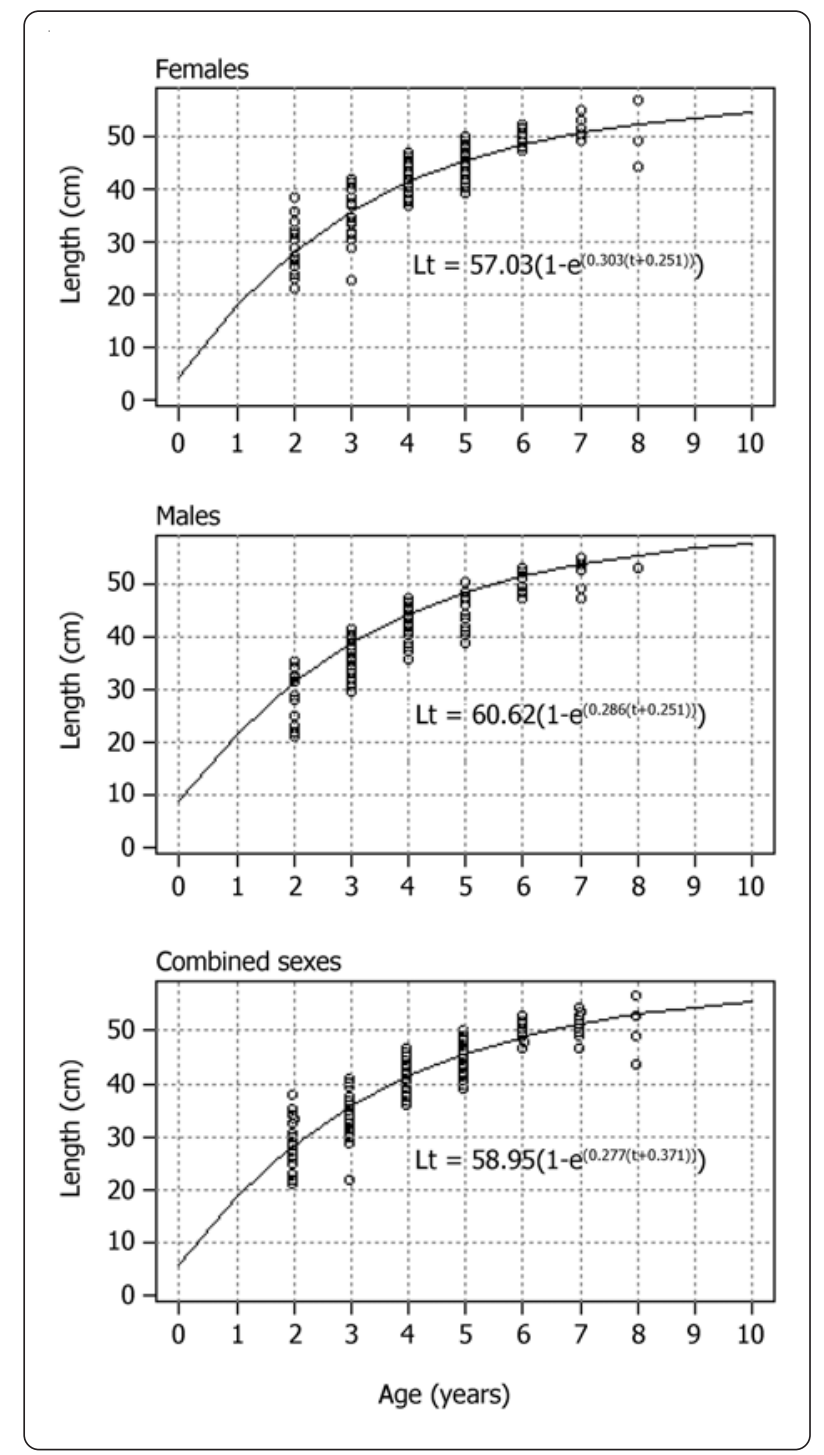

Figure 3. Length growth curve for females, male and for combined sexes of southern rays breams / Curva de crecimiento en longitud para hembras, machos y sexos combinados de reineta

The total mortality rates $(\mathrm{Z})$ were determined from the descending limb of the resulting curve for catch-at-age, considering a maximum observed age of 11 years for the combined sexes. A regression estimate obtained from the slope of a catch-curve truncated at older ages (Fig. 5) was $\mathrm{Z}=0.9 \mathrm{yr}^{-1}$. On the other hand, using growth parameters for pooled data, $\mathrm{M}$ was estimated in $0.46 \mathrm{yr}^{-1}$ following Pauly (1980). The mean habitat temperature of $14^{\circ} \mathrm{C}$ was assumed for calculating $\mathrm{M}$ with this method. The M value obtained with Alagaraja (1984) method was $0.44 \mathrm{yr}^{-1}$, using 11 years to $\mathrm{T}_{1}$. A compromise value of 0.45 $\mathrm{yr}^{-1}$ was assumed to $\mathrm{M}$ in B. australis.

\section{Discussion}

This paper presents new information about important biological aspects of Brama australis in the eastern South Pacific and the results may be used to prove potential temporal changes in growth parameters and natural mortality.

The reports of biological and ecological data for $B$. australis are restricted to taxonomical studies (Pavlov 1991a, b), feeding ecology (Muñoz et al. 1995), and reproduction dynamics (Pavlov 1994, Leal \& Oyarzún 2003). Furthermore, several studies of population dynamics have targeted congeneric species of Brama inhabiting other latitudes for purposes of commercial exploitation and management. This interesting fishery has been explored off the coasts of Australia, New Zealand, Spain, and Portugal (Seki \& Mundi 1991, Savinykch 1993, Last \& Baron 1994).

The generalized VBGF satisfactorily described the growth of B. australis, and the similar growth curves for males and females provided a graphic representation of the lack of significant differences in mean length-at-age by sex. A slight difference was observed between sexes in terms of length, possibly due to different proportions of length in the sampled individuals: despite a 1:1 proportion of sexes, females tended to be slightly larger than males.

Interestingly, in this study most of the sampled specimens were adults. The lack of juveniles in the study could result in overestimated values of the growth parameters (Francis \& Campana 2004). Nevertheless, this result agrees with the reports about other species of Brama (Pavlov 1991b, Savinykh 1994,1995; Seki \& Bigelow 1996), indicating the possibility of differential bathymetric distributions for juveniles (pelagic-coastal) and adults (oceanic-demersal), or the lack of selectivity of the gears for sampling this etary group. On the other hand, perhaps the strongest alternative explanation for the lack of youngof-the-year lies in the migratory patterns observed in many bramids. Specifically, breams undergo long-range migrations along the oceanic water mass according to circumtropical circulation (Seki \& Mundi 1991). Pavlov (1994) suggests a feeding migration of B. australis from north to south in summer-autumn and from south to north in winter-spring to spawn.

Our results about age (2 to 8 years) in B. australis observed ranged from 21 to $58 \mathrm{~cm} T_{\mathrm{L}}$ are consistent with Pavlov (1994) which suggested one to 6 age group to a few sample number of $13-48 \mathrm{~cm}$ B. australis from southeast 


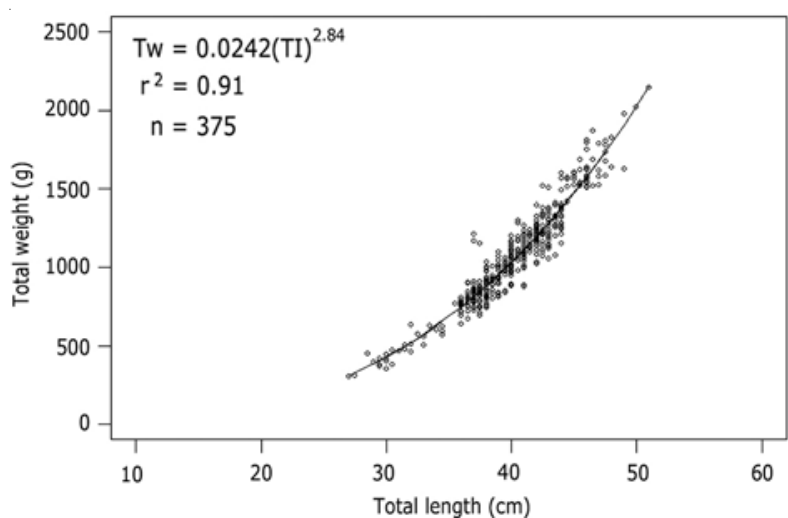

Figure 4. Length-weight relationship curve of southern rays breams fitted to an exponential model / Curva de la relación longitudpeso de reineta ajustada por un modelo exponencial

Pacific Ocean. For Brama japonica, Savinykh \& Vlasova (1994) examined whole stained otoliths of $14-54 \mathrm{~cm}$ from the North Pacific and found a maximum age of 9 years, with 3 and 4 year fish predominating in the catch. For the same species, rapid growth is observed during the first 3 years, when they reach $80 \% \mathrm{~L}_{\infty}$ (Pearcy et al. 1993). This species reaches its asymptotic length at approximately 9 to 11 years of age. Lobo \& Erzini (2001) used readings of whole otoliths for $32-56 \mathrm{~cm} \mathrm{~B}$. brama from Portugal to identify age groups 3 to 12 years.

Both the growth trends and the age and growth parameters obtained in this study agree with those reported for $B$. japonica and $B$. brama with a maximum asymptotic length observed near $60 \mathrm{~cm}$ (TL), although only 4 of the specimens used in this study were larger than $55 \mathrm{~cm} L_{\mathrm{T}}$.

The previous background support maximum ages of 8 to 12 years for species of Brama and seem reasonable for a middle size of pelagic fish. This also supports the annual formation of translucent zones (hialine bands) observed in this study.

This work is the first study on age, growth, and mortality for Brama australis in the Chilean coast based on otolith analysis, so no comparison is possible with other studies of this species. When compared with the total mortality rates $(\mathrm{Z})$, estimates of $\mathrm{M}$ are consistent. The yield, explotation rates, and F/M ratio are lower than those reported for other species exploited in this area (Böhm et al. 1995). However, the natural mortality rate seems to be consistent with the life parameters of middlesized pelagic fishes with relatively low exploitation at the time of sampling.

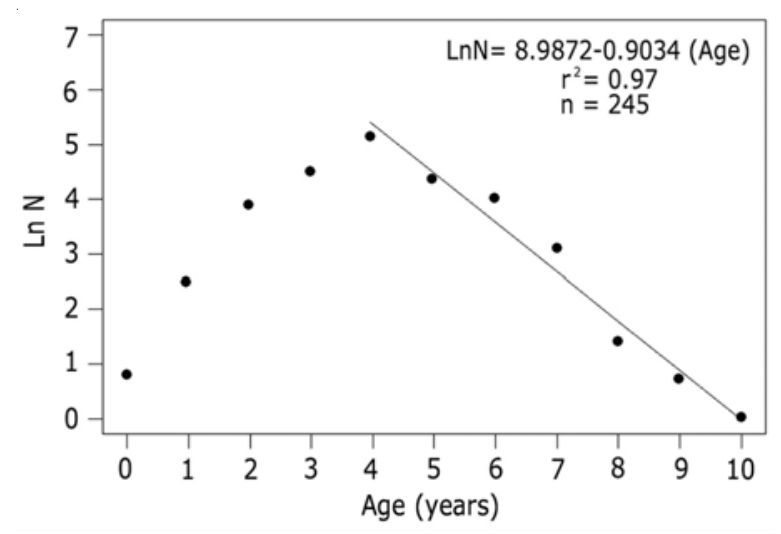

Figure 5. Catch-curve and estimate of total mortality for southern rays breams / Curva de captura y tasa de mortalidad total estimada para reineta

Thus, considering the time in which samples were obtained, when the resource was still subject to lowmoderate exploitation rates, the results of this report provide an important point of comparison with current or future studies. For example, to assess possible fishing effects on individual growth rates and $\mathrm{M}$. The parameters may also be used in stock assessment analysis providing management advice for fishery along the Chilean coast.

\section{ACKNOWLedgments}

We thank the workers of the Instituto de Fomento Pesquero (IFOP) for helping us obtain samples. Special thanks to Mrs. Ana Lara for assistence with otolith reading and to Dr. Rubén Roa for helpful comments on the manuscript.

\section{LITERATURE CITED}

Alagaraja K. 1984. Simple methods for the estimation of parameters of assessing exploited fish stocks. Indian Journal of Fishes 31: 177-208.

Beamish R \& D Fournier. 1981. A method for comparing the precision of a set of age determination. Canadian Journal of Fisheries and Aquatic Sciences 38: 982-983.

Böhm G, H Muñoz, V Bocic, R Serra, M Nilo, M Donoso, MA Barbieri \& G Rosson. 1995. Diagnóstico de las principales pesquerías nacionales pelágicas zona centro sur1994, 121 pp. Corporación de Fomento de la Producción. Instituto de Fomento Pesquero, Valparaíso.

Chen Y, D Jackson \& H Harvey. 1992. A comparison of von Bertalanffy and polynomial functions in modeling fish growth data. Canadian Journal of Fisheries and Aquatic Sciences 49: 1228-1235. 
Francis R \& S Campana. 2004. Inferring age from otolith measurements: a review and a new approach. Canadian Journal of Fisheries and Aquatic Sciences 61: 1269-1284.

Garcia M \& J Chong. 2002. Composición de la dieta de Brama australis Valenciennes 1837 en la zona centro sur de Chile (VIII región) en otoño de 2000 y verano de 2001. Gayana 66: 225-230.

Last P \& M Baron. 1994. Rays bream- a new pelagic fishery? Australian-Fisheries 53: 19-22.

Leal E \& C Oyarzún. 2003. Talla de madurez y época de desove de la reineta (Brama australis Valenciennes, 1836) en la costa central de Chile. Investigaciones Marinas 31: 17-24.

Lobo C \& K Erzini. 2001. Age and growth of Ray's bream (Brama brama) from the south of Portugal. Fisheries Research 51: 343-347.

Mead GW. 1972. Bramidae. Dana-Report 81: 1-175.

Muñoz G, N Cortés, M Arriaza \& C Oyarzún. 1995. Comportamiento trófico de una especie poco conocida, Brama australis Valenciennes, 1837 (Pisces: Bramidae). Biología Pesquera 24: 51-55.

Pauly D. 1980. On the inter-relationships between natural mortality, growth parameters and mean environmental temperature in 175 fish stocks. ICES 39: 175-192.

Pavlov YP. 1991a. Brama australis Valenciennes-A valid species of Sea Bream (Bramidae) from Southeastern Pacific Ocean. Journal of Ichthyology 31: 6-9.

Pavlov YP. 1991b. Information on morphometrics and ecology of pomfrets of the genus Brama inhabiting the southeastern Pacific Ocean. Journal of Ichthyology 31: 120-124.

Pavlov YP. 1994. Data on ecology of Sourthern pomfret, Brama australis in the southeastern Pacific Ocean. Journal of Ichthyology 34: 124-126.
Ricker WE. 1975. Computation and interpretation of biological statistics of fish populations. Journal of the Fisheries Research Board of Canada 191: 1-382.

Savinykh VF. 1993. Some ecological characteristics of young pomfret in the Northwest Pacific. Marine Biology 2: 7783.

Savinykh VF. 1994. Size-age structure and growth rate of the Pacific Pomfret Brama japonica. Voprosy Ikhtiology 34: 494-500.

Savinykh VF. 1995. Migrations of the Pacific Pomfret Brama japonica. Russian Journal of Marine Biology 20: 271-277.

Savinykh V \& L Vlasova. 1994. Size-age structure and growth rate of the Pacific pomfret Brama japonica (Bramidae). Journal of Ichthyology 34(8): 97-107.

Seki M \& K Bigelow. 1996. Aspects of the life history of the Pacific Pomfret, Brama japonica, during winter occupation of the Subtropical Frontal Zone. International Bulletin of the North Pacific Commission 53: 207-215.

Seki M \& B Mundy. 1991. Some notes on the early life stages of the Pacific Pomfret, Brama japonica, and other Bramidae from the Central North Pacific Ocean. Japanese Journal of Ichthyology 38: 63-68.

SERNAPESCA. 2011. Anuario estadístico de pesca, 291 pp. Ministerio de Economía Fomento y Reconstrucción, Santiago.

Smith ST. 1990. Use of statistical models for the estimation of abundance from groundfish trawl survey data. Canadian Journal of Fisheries and Aquatic Sciences 47: 894-903.

Sparre P \& S Venema. 1997. Introduction to tropical fish stock assessment. FAO Fisheries Technical Report 306: 1337.

Received 30 January 2013 and accepted 18 October 2013

Associate Editor: Mauricio Landaeta D. 